\title{
ANALISIS BUKU BAHASA ARAB PENDEKATAN SAINTIFIK KURIKULUM 2013 MADRASAH IBTIDAIYAH KELAS I
}

\author{
Martatik \\ Pusdiklat Tenaga Teknis Pendidikan dan Keagamaan \\ martatik75@gmail.com
}

\begin{abstract}
ABSTRAK
Penelitian ini bertujuan untuk mengetahui dan menjamin kelayakan buku ajar Bahasa Arab Madrasah Ibtidaiyah Kelas I, yang diterbitkan oleh Kementerian Agama, disesuaikan dengan standar yang telah ditetapkan. Metode penelitian adalah metoda deskriptif kualitatif dengan mereview dokumen sebagai total populasi, disesuaikan dengan kriteria tertentu. Dokumentasi tersebut berasal dari data Puslitbang Lektur, Khazanah Keagamaan dan Manajemen Organisasi. Hasil penelitian, ditemukan fakta di lapangan, masih banyak kesalahan pada buku ajar Pendidikan Agama Islam yang digunakan di Madrasah, baik dari sisi teknik maupun substansi buku, dan diperlukan berbagai perbaikan untuk dijadikan bahan buku ajar.
\end{abstract}

Kata Kunci: review, kriteria, standar

\section{ABSTRACT}

This study aims to find out and guarantee the feasibility of the textbooks of Arabic Madrasah Ibtidaiyah for Class I, published by the Ministry of Religious Affairs, in accordance with predetermined standards. The research method is qualitative descriptive method by reviewing the document as total population, adjusted with certain criteria. The documentation is derived from the data of Center for Research and Development Lektur, Khazanah, Religious and Organizational Management. The results of the research, found in fact in the field, there are still many mistakes in the textbook of Islamic Religious Education used in Madrasah, both in terms of technical and book substance, and needed various improvements to be used as textbook material.

Keywords: review, criteria, standard 
PENDAHULUAN

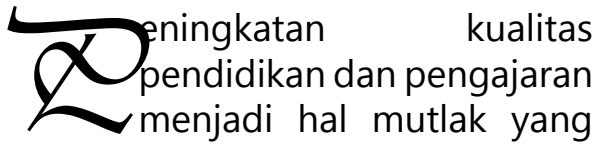

harus dilakukan oleh pemerintah. Salah satu usaha yang dilakukan untuk menunjang peningkatan kualitas pendidikan dan pengajaran adalah dengan pengadaan buku ajar di sekolah (Darwis, 1989:296). Ketersediaan buku ajar yang berkualitas akan mendukung keberhasilan proses pembelajaran. Buku ajar bisa berpengaruh kuat dalam memberikan pengalaman belajar siswa (Darwis, 1989:296). Buku sebagai salah satu sumber dan media dalam belajar turut menentukan tercapainya tujuan pembelajaran.

Buku Guru dan Buku Siswa mata pelajaran Pendidikan Agama Islam pada Madrasah yang terdiri dari buku Alquran Hadits, Aqidah Akhlak, Fiqih, SKI, dan Bahasa Arab, disusun berdasarkan Peraturan Menteri Agama Republik Indonesia Nomor: 165 Tahun 2014 Tentang Kurikulum 2013 Mata Pelajaran Pendidikan Agama Islam dan Bahasa Arab Pada Madrasah. Buku guru dan buku siswa pada Madrasah yang disediakan oleh Kementerian Agama merupakan "dokumen hidup". Hal ini berarti bahwa buku-buku tersebut akan selalu diperbaiki, diperbaharui, dan dimutakhirkan sesuai dengan dinamika kebutuhan dan perubahan zaman.
Di sisi lain, proses pengadaan buku guru dan buku siswa untuk Kurikulum 2013 yang terkesan sangat tergesa-gesa karena adanya desakan kebijakan pemberlakuan kurikulum 2013, memungkinkan terjadinya beberapa kekurangan dan kesalahan. Oleh karena itu proses review terhadap buku-buku tersebut mutlak dilaksanakan, terlebih lagi untuk buku Pendidikan Agama Islam pada Madrasah, yang memerlukan ketelitian dan kecermatan lebih, terkait unsur tadqiq. Tadqiq adalah kegiatan menyunting konten buku, meliputi: transliterasi, penulisan ayat dan terjemah, penulisan hadis serta sumber dan terjemahnya, penulisan rujukan, dan sistematika penulisan. (Edukasi, 2016, hal. 82). Tadqiq juga dimaknai sebagai penelitian dan penilaian terhadap kebenaran sesuatu (Puslitbang Lektur Keagamaan, 2009: iii).

Kenyataan di lapangan, ditemukan banyak sekali kesalahan pada sebagian buku Pendidikan Agama Islam pada Madrasah baik berupa kesalahan teknis maupun substantif serta kesalahan pada aspek penulisan, transliterasi, serta terjemahan ayat-ayat Alquran dan Hadis yang tidak sesuai dengan standar Kementerian Agama. Untuk memelihara kesahihan materi dan kesahihan penulisan ayatayat Alquran dan Hadis baik dari aspek penulisan ayat, transliterasi, maupun terjemahannya perlu dilakukan review (penilaian) 
terhadap buku-buku Pendidikan Agama Islam pada sekolah dan madrasah.

Buku ajar biasanya disusun oleh seorang penulis atau tim penulis berdasarkan kurikulum atau interpretasi terhadap kurikulum yang berlaku. Buku sebagai sumber belajar wajib di sekolah-sekolah, tidak selamanya disediakan oleh pemerintah. Namun Pemerintah memiliki tanggungjawab untuk menjamin kualitas buku sesuai dengan kurikulum yang berlaku. Kementerian Agama memiliki tanggungjawab menjamin kualitas buku ajar yang digunakan di Satuan Pendidikan di Kementerian Agama. Dalam hal ini Puslitbang Lektur, Khazanah Keagamaan dan Manajemen Organisasi ditunjuk oleh Kementerian Agama sebagai lembaga penjamin mutu buku ajar yang akan dipergunakan di Kementerian Agama.

Sementara itu, menurut penelitian yang dilakukan oleh Puslitbang Lektur dan Khazanah Keagamaan pada tahun 2015, masih banyak ditemukan kesalahankesalahan pada buku Pendidikan Agama Islam yang diterbitkan oleh Kementerian Agama. Kesalahankesalahan tersebut antara lain adalah ketidaktepatan pengutipan teks ayat Alquran karena tidak sesuai dengan Alquran Standar yang diterbitkan oleh Kementerian Agama ketidaktepatan dalam pengutipan hadis ketidaktepatan dalam pengutipan terjemah ayat Alquran, ketidaktepatan dalam penerjemahan hadis, inkonsistensi dalam penggunaan transliterasi Arab-Latin, ketidaktepatan dalam penulisan Bahasa Indonesia, ketidaksesuaian antara pengutipan ayat Alquran atau hadis dengan topik bahasan, ketidaksesuaian antara materi dengan gambar (ilustrasi), dan, ilustrasi yang ditampilkan sering tidak sesuai dengan konteks pembahasan atau usia anak didik, daftar pustaka yang dicantumkan sering tidak dirujuk karena sering menggunakan sumber yang tidak kredibel seperti internet. (Jakarta, NU online, Selasa, 22 November 2016)

Berdasarkan permasalahan di atas, penulis melakuan penelitian terhadap kelayakan Buku Ajar Bahasa Arab Kelas I Madrasah Ibtidaiyah Kurikulum 2013. Penelitian ini dilakukan untuk mengetahui apakah buku Bahasa Arab Madrasah Ibtidaiyah Kelas I Kurikulum 2013 memiliki kelayakan sebagai bahan ajar dari aspek isi, penyajian, kegrafikaan, bahasa dan tadqiq.

Tujuan dari penelitian ini adalah untuk melakukan penilaian terhadap buku Bahasa Arab MI Kurikulum 2013, disesuaikan dengan standar Kementerian Agama, dari aspek isi, penyajian, bahasa kegrafikaan dan aspek tadqiq. 


\section{Buku Siswa dan Buku Guru Kurikulum 2013}

Buku Siswa

Buku Siswa adalah buku yang diperuntukan bagi siswa yang dipergunakan sebagai panduan aktifitas pembelajaran untuk memudahkan siswa dalam menguasai kompetensi tertentu. Buku Siswa bukan sekedar bahan bacaan, tetapi juga digunakan untuk melaksanakan kegiatan-kegiatan dalam proses pembelajaran (activities based learning) isinya dirancang dan dilengkapi dengan contoh-contoh lembar kegiatan dengan tujuan agar dapat terselenggaranya pembelajaran kontekstual, artinya siswa dapat mempelajari sesuatu yang relevan dengan kehidupan yang dialaminya.

Buku Siswa disusun untuk memfasilitasi siswa mendapat pengalamanbelajaryangbermakna. Isi sajian buku diarahkan agar siswa lebih aktif dalam mengikuti proses pembelajaran melalui kegiatan mengamati, menanya, menalar, mencoba, berdiskusi serta meningkatkan kemampuan berkomunikasi baik antar teman maupun dengan gurunya. Melalui kegiatan-kegiatan tersebut diharapkan dapat menumbuhkan motivasi, rasa keiingintahuan, inisiatif, dan kreatifitas peserta didik. Walaupun telah disusun sedemikian rupa, guru masih dapat mengembangkan atau memperkaya materi dan kegiatan lain yang sesuai dengan tujuan pembelajaran yang telah ditetapkan. (Shobirin, 2016: 169)

Buku Siswa merupakan buku sumber belajar bagi siswa/ peserta didik yang memuat hal-hal berikut, yaitu: Judul bab, infomasi kompetensi dasar yang sesuai dengan topik pada setiap bab. Pada setiap bab dilengkapi dengan peta konsep, pengantar, bagian kegiatan siswa baik ekperimen maupun non eksperimen atau diskusi, latihan soal, rangkuman, evaluasi, dan tugas bagi peserta didik. Penggunaan Buku Siswa oleh peserta didik disarankan dimulai dengan membaca dan mengkaji bagian pengantar bab atau subbab, melakukan kegiatan-kegiatan yang tersedia, mendiskusikan hasil kegiatan dan memverifikasi hasil diskusi dengan informasi konsep yang ada di buku. Uraian materi lainnya merupakan bagian untuk memperdalam pemahaman konsep dan diakhiri dengan soalsoal untuk menguji pemahaman konsep secara individual. (Kementerian Pendidikan dan Kebudayaan, 2014:78)

Buku Guru

Buku Guru merupakan pedoman bagi guru dalam melaksanakan pembelajaran yang meliputi persiapan, pelaksanaan dan penilaian serta pedoman penggunaan buku siswa. Buku Guru terdiri dari dua bagian, yaitu 
petunjuk umum pembelajaran dan petunjuk khusus pelaksanaan pembelajaran pada setiap bab sesuai dengan Buku Siswa. Petunjuk umum pembelajaran berisi informasi tentang cakupan dan lingkup materi pembelajaran, tujuan pembelajaran, strategi pembelajaran yang meliputi pendekatan, model dan metode, penjelasan tentang media dan sumber belajar serta prinsip-prinsip penilaian pada pembelajaran.

Petunjuk khusus pembelajaran terdiri dari beberapa bab sesuai dengan materi pada Buku Siswa. Umumnya, petunjuk khusus berisi informasi bagiguru untuk persiapan pelaksanaan pembelajaran dan penilaian pembelajaran pada bab tersebut. Pada umumnya bagian ini berisi: peta konsep untuk materi pada bab ini, cakupan materi untuk tatap muka, KI dan KD yang sesuai dengan materi, alokasi waktu dan rincian materi setiap tatap muka. Selanjutnya pada bagian ini terdapat uraian pembelajaran untuk setiap tatap muka, mulai dari tujuan pembelajaran, alternatif kegiatan pembelajaran, sumber belajar dan media pembelajaran.

Bagian penilaian berisi informasi tentang teknik dan bentuk penilaian oleh guru, penilaian diri, penilaian antar peserta didik dan informasi pembahasan soal pada buku siswa. Pada buku guru juga ada informasi bagaimana cara informasi komunikasi dengan
Orangtua/Wali. (Kementerian Pendidikan dan Kebudayaan, 2014:78)

Buku Guru dan Buku Siswa merupakan standar minimal yang dapat dikembangkan jika guru merasa perlu mengembangkannya sesuai dengan kondisi sekolah, terutama yang berkaitan dengan kegiatan pembelajaran, guru dapat menyesuaikan sesuai dengan alat dan bahan praktikum atau media belajar yang tersedia di sekolah atau model-model pembelajaran yang dipilih guru. (Kementerian Pendidikan dan Kebudayaan, 2014:78)

\section{METODE PENELITIAN}

Metode penelitian yang digunakan dalam penelitian ini adalah deskriptif kualitatif dengan teknik tadqiq yaitu penelitian dan penilaian terhadap kebenaran sesuatu naskah. Obyek penelitian ini adalah Buku Siswa dan Buku Guru Bahasa Arab Pendekatan Saintifik Kurikulum 2013, Madrasah Itidaiyah Kelas I. Aspek yang diteliti/dinilai dan metode yang digunakan kali ini mengacu pada hasil pelatihan dan couching yang dilakukan oleh Puslitbang Lektur, Khazanah Keagamaan, dan Manajemen Keorganisasian Kementerian Agama Republik Indonesia tahun 2017, di Pusdiklat Tenaga Teknis Pendidikan dan Keagamaan, Badan Litbang dan 
Diklat Kementerian Agama. Aspekaspek yang diteliti adalah sebagai berikut:

\section{Aspek isi}

Kriteria penilaian pada aspek isi adalah a) materi buku ajar mampu menjaga persatuan dan kesatuan bangsa serta terhindar dari unsur ketidakpatutan; b) memenuhi ketentuan umum yang berlaku, c) mendukung ketercapaian kompetensi sesuai dengan kurikulum yang berlaku, d) memberikan manfaat pengembangan wawasan bagi pembaca, memenuhi kecukupan materi, ilustrasi, latihan dan tugas; e) materi yang disampaikan akurat, f) menggunakan metode yang terbaru, g) memiliki makna yang utuh; serta $h$ ) uraian materi proporsional. Dari kriteria-kriteria tersebut dikembangkan menjadi 47 indikator penilaian.

Aspek Penyajian

Aspek penyajian terdiri dari empat (4) kriteria, yaitu: a) memenuhi kelengkaan sajian; b) memiliki keruntutan alur, c) memuat daftar pendukung yang lengkap, serta d) mendorong aktivitas pembelajaran peserta didik. teknik penyajian, pendukung sajian dan aktifitas pembelajaran. Kriteria penilaian dikembangkan lagi menjadi 23 indikator penilaian.
Aspek Bahasa

Kriteria penilaian pada aspek bahasa adalah: a) kesesuaian dengan tingkat perkembangan berfikir peserta didik; b) menggunakan bahasa yang mudah difahami; c) kesesuaian dengan kaidah bahasa Indonesia yang baik dan benar; serta d) memiliki keruntutan dan kesatuan gagasan. Pasa aspek ini, terdapat 16 indikator penilaian.

Aspek Kegrafikaan (desain dan tata letak buku).

Pada aspek ini terdapat 5 kriteria penilaian, yaitu: a) Memiliki ukuran yang pas; b) Memiliki tampilan menarik; c) Huruf yang digunakan mudah terbaca; d) sesuai dengan isi buku dan e) keteraturan isi buku. Kelima krietria tersebut dikembangkan lagi menjadi 20 indikator penilaian.

Aspek tadqiq (aspek transliterasi dan keakuratan pengutipan ayat-ayat Alquran dan hadis serta terjemahannya

Aspek tadqiq ini memiliki 4 kriteria penilaian, yaitu: a) memenuhi ketepatan penulisan atau pengutipan ayat dan terjemahannya sesuai Alquran tandar Kementerian Agama; b) memenuhi ketepatan penulisan dan pengutipan hadis serta terjemahannya sesuai dengan kitab hadis standar; c) memenuhi standar penulisan transliterasi sesuai SKB Menteri Agama 
dan Mendikbud 1987; serta d) memenuhi ketepatan pengutipan Alquran dan hadis sesuai dengan kebutuhan pembelajaran. Masingmasing kriteria dikembangan lagi menjadi 3 indikator penilaian, sehingga dalam aspek ini terdapat 12 indikator penilaian.

Penilaian dilakukan dengan mencermati secara keleseluruhan buku, kata perkata mulai dari cover depan buku sampai cover belakang buku, dengan memperhatikan indikator-indikator penilaian. Adapun dalam pelaporannya, penilaian ini menyajikan matrik penilaian, yang terdiri dari posisi dalam teks buku, kesalahan, pembetulan, serta beberapa keterangan yang diperlukan. Hal ini bertujuan agar dapat dilakukan perbaikan yang mendetail terhadap kesalahan-kesalahan yang ditemukan.

\section{HASIL DAN PEMBAHASAN}

\section{Hasil}

a. Buku Siswa Bahasa Arab Pendekatan Saintifik Kurikulum 2013, Madrasah Ibtidaiyah Kelas I.

Tabel 1. Daftar Temuan Aspek Isi Buku Siswa Bahasa Arab Kelas I Madrasah Ibtdaiyah

\begin{tabular}{|c|c|c|c|c|c|}
\hline \multirow[b]{2}{*}{ NO } & \multicolumn{2}{|c|}{ POSISI TEKS } & \multirow[b]{2}{*}{$\begin{array}{l}\text { TEMUAN } \\
\text { KESALAHAN }\end{array}$} & \multirow[b]{2}{*}{ PEMBETULAN } & \multirow[b]{2}{*}{ KETERANGAN } \\
\hline & HIm. & Nomor./Alinea & & & \\
\hline 1. & $\mathrm{~V}$ & $\begin{array}{l}\text { Alenia } 2 \text { dan } \\
3\end{array}$ & $\begin{array}{l}\text { Memuat kalimat } \\
\text { yang tidak terlalu } \\
\text { penting untuk } \\
\text { dimuat karena tidak } \\
\text { sesuai dengan } \\
\text { pembahasan }\end{array}$ & $\begin{array}{l}\text { Tidak perlu } \\
\text { dimuat dalam } \\
\text { pengantar }\end{array}$ & $\begin{array}{l}\text { Tidak sesuai } \\
\text { dengan konteks } \\
\text { pembahasan }\end{array}$ \\
\hline 2. & vii & Baris ke 2 & عُمْتَوِيَاتُ & 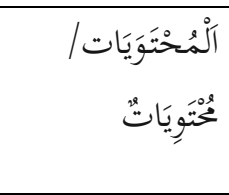 & $\begin{array}{l}\text { Menggunakan } \\
\text { kata ma'rifah } \\
\text { dengan Jlatau } \\
\text { nakirah dengan } \\
\text { tanwin }\end{array}$ \\
\hline 3 & vii & Baris ke 8 & تَتَّرِيْنَاتُ & تَتَرِينَاتُ & $\begin{array}{l}\text { Diakhiri dengan } \\
\text { dammatain }\end{array}$ \\
\hline 4 & viii & Baris ke 1 & عُحتِوِيَاتُ & 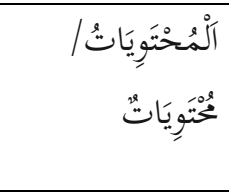 & $\begin{array}{l}\text { Menggunakan } \\
\text { kata ma'rifah } \\
\text { dengan ال atau } \\
\text { nakirah dengan } \\
\text { tanwin }\end{array}$ \\
\hline 5 & ix & Baris ke 1 & إفْتَحْ & إفتْتَحْ & $\begin{array}{l}\text { Menggunakan alif } \\
\text { bukan hamzah }\end{array}$ \\
\hline 6 & ix & Baris ke 3 & أُنْظُْْ & أنْظُرْ & $\begin{array}{l}\text { Menggunakan alif } \\
\text { bukan hamzah }\end{array}$ \\
\hline
\end{tabular}




\begin{tabular}{|c|c|c|c|c|c|}
\hline 7 & ix & $\begin{array}{l}\text { Baris 3, 5, 7, } \\
9\end{array}$ & 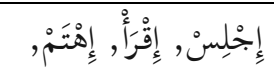 & إِجِلِسن , إقَرَأَ, & $\begin{array}{l}\text { Diawali dengan } \\
\text { alif, bukan hamzah }\end{array}$ \\
\hline 8 & $x$ & $\begin{array}{l}\text { Baris ke 1dan } \\
\text { ke } 3\end{array}$ & 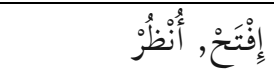 & إِفْتَخْ, اُنُّْْ & $\begin{array}{l}\text { Diawali dengan } \\
\text { alif, bukan hamzah }\end{array}$ \\
\hline 9 & 29 & Baris ke 1 & & & $\begin{array}{l}\text { Diakhiri degan } \\
\text { dammatain }\end{array}$ \\
\hline 10 & 29 & Baris ke 14 & & & $\begin{array}{l}\text { Menggunakan alif } \\
\text { bukan hamzah }\end{array}$ \\
\hline 11 & 29 & Baris ke 14 & & إسمْْكَكَ & $\begin{array}{l}\text { Menggunakan alif } \\
\text { bukan hamzah }\end{array}$ \\
\hline 12 & 35 & 7 & & & $\begin{array}{l}\text { Menggunakan alif } \\
\text { awal kata, bukan } \\
\text { hamzah, kasrah di } \\
\text { akhir, bukan } \\
\text { dhammatain }\end{array}$ \\
\hline 13 & 38 & 4 & & إثْنَانَ & $\begin{array}{l}\text { Tanpa hamzah di } \\
\text { awal }\end{array}$ \\
\hline 14 & 43 & 9 & اَلْأَرْبَعَاءُ & آلالََْْْبَعَاءُ & $\begin{array}{l}\text { Tanpa tanwin di } \\
\text { akhir }\end{array}$ \\
\hline 15 & $\begin{array}{l}55 \\
53 \\
54 \\
55 \\
56 \\
58 \\
59\end{array}$ & $\begin{array}{l}1,2,3,4 \\
1,7,8 \\
1,2,6,8,9 \\
1,2,3,4,6, \\
7,4,3,5 \\
8\end{array}$ & 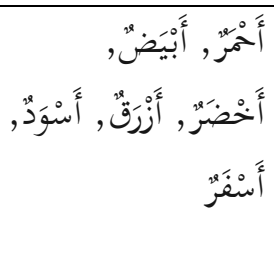 & 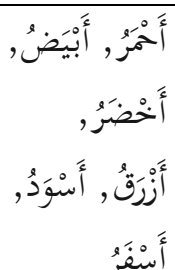 & $\begin{array}{l}\text { Semua diakhiri } \\
\text { dengan dammah, } \\
\text { bukan dammatain }\end{array}$ \\
\hline 16 & 57 & 8 & الثْنَان & إنَْْان & $\begin{array}{l}\text { Tanpa hamzah di } \\
\text { awal }\end{array}$ \\
\hline
\end{tabular}

Tabel 2. Daftar Temuan Aspek Penyajian Buku Siswa Bahasa Arab Madrasah Ibtidaiyah Kelas I

\begin{tabular}{|c|c|c|c|c|c|}
\hline NO & HLM & POSISI TEKS & $\begin{array}{c}\text { TEMUAN } \\
\text { KESALAHAN }\end{array}$ & PEMBETULAN & KETERANGAN \\
\hline 1 & iv & $\begin{array}{l}1,4,7,9,10, \\
12,14,17 \\
1,12,15,18, \\
20,23,25 \\
9,11,13,23, \\
25\end{array}$ & $\begin{array}{l}\text { menciptakan, kepada, } \\
\text { Indonesia, kerukunan, } \\
\text { untuk, menyerasikan, } \\
\text { seluruh, kembang, } \\
\text { bukan, lingkungan, } \\
\text { ilmu-ilmu, madrasah, } \\
\text { sejarah, madrasah, } \\
\text { sarananya, untuk, } \\
\text { berinovasi, pertama, } \\
\text { karena, perbaikan, } \\
\text { penerbitan, }\end{array}$ & $\begin{array}{l}\text { menciptakan, kepada, } \\
\text { Indonesia, kerukunan, } \\
\text { untuk, menyerasikan, } \\
\text { seluruh, kembang, } \\
\text { bukan, lingkungan, } \\
\text { ilmu-ilmu, madrasah, } \\
\text { sejarah, madrasah, } \\
\text { sarananya, untuk, } \\
\text { berinovasi, pertama, } \\
\text { karena, perbaikan, } \\
\text { penerbitan, }\end{array}$ & $\begin{array}{l}\text { Terdapat banyak } \\
\text { pemenggalan } \\
\text { suku kata yang } \\
\text { kurang tepat } \\
\text { karena pergantian } \\
\text { baris.. }\end{array}$ \\
\hline
\end{tabular}




\begin{tabular}{|l|l|l|l|l|l|}
\hline 2 & iv & Baris terahir & $\begin{array}{l}\text { Satu baris kepala } \\
\text { alinea menggantung } \\
\text { di akhir halaman }\end{array}$ & $\begin{array}{l}\text { Dipindahkan ke } \\
\text { halaman beerikutnya }\end{array}$ & \\
\hline
\end{tabular}

Tabel 3. Daftar Temuan Aspek Bahasa Buku Siswa Bahasa Arab Madrasah Ibtiaiyah Kelas I

\begin{tabular}{|c|c|c|c|c|c|}
\hline NO & HLM & POSISI TEKS & $\begin{array}{l}\text { TEMUAN } \\
\text { KESALAHAN }\end{array}$ & PEMBETULAN & KETERANGAN \\
\hline 1 & iii & Alinea ke 3 & $\begin{array}{l}\text { a) Alquran-Hadis b) } \\
\text { Akidah } \\
\text { Akhlak c) Fikih d) } \\
\text { Sejarah Kebudayaan } \\
\text { Islam. Pada jenjang } \\
\text { Madrasah Aliyah } \\
\text { Peminatan Ilmu-ilmu } \\
\text { Keagamaan dikem- } \\
\text { bangkan } \\
\text { kajian khusus mata } \\
\text { pelajaran yaitu: a) } \\
\text { Tafsir-Ilmu Tafsir b) } \\
\text { HadisIlmu Hadis c) } \\
\text { Fikih-Ushul Fikih d) } \\
\text { Ilmu Kalam dan e) } \\
\text { Akhlak. }\end{array}$ & $\begin{array}{l}\text { Alquran-Hadis, b) } \\
\text { Akidah } \\
\text { Akhlak, c) Fikih, d) } \\
\text { Sejarah Kebu- } \\
\text { dayaan Islam. Pada } \\
\text { jenjang Madrasah } \\
\text { Aliyah Peminatan } \\
\text { Ilmu-ilmu Keag- } \\
\text { amaan dikembang- } \\
\text { kan } \\
\text { kajian khusus mata } \\
\text { pelajaran yaitu: a) } \\
\text { Tafsir-Ilmu Tafsir, b) } \\
\text { HadisIlmu Hadis, c) } \\
\text { Fikih-Ushul Fikih, d) } \\
\text { Ilmu Kalam, dan e) } \\
\text { Akhlak. }\end{array}$ & $\begin{array}{l}\text { Tidak ada tanda } \\
\text { baca koma untuk } \\
\text { memisahkan un- } \\
\text { sur-unsur dalam } \\
\text { suatu rincian }\end{array}$ \\
\hline 2 & V & 1 & $\begin{array}{l}\text { BukuPegangan } \\
\text { Siswa dan Buku } \\
\text { Pedoman Guru. }\end{array}$ & $\begin{array}{l}\text { Buku Siswa dan } \\
\text { Buku Guru. }\end{array}$ & $\begin{array}{l}\text { Menggunakan } \\
\text { istilah yang tidak } \\
\text { konsisten }\end{array}$ \\
\hline 3 & V & Alinea 4 & $\begin{array}{l}\text { keberadaan Buku } \\
\text { Ajar dalam pen- } \\
\text { erapan Kurikulum } \\
2013 \text { di } \\
\text { Madrasah menjadi } \\
\text { sangat penting dan } \\
\text { menentukan, }\end{array}$ & $\begin{array}{l}\text { keberadaan Buku } \\
\text { Ajar dalam pen- } \\
\text { erapan Kurikulum } \\
2013 \text { di } \\
\text { Madrasah menjadi } \\
\text { sangat penting } \\
\text { dan menentukan } \\
\text { keberhasilan pem- } \\
\text { belajaran }\end{array}$ & $\begin{array}{l}\text { Kalimat belum } \\
\text { sempurna, belum } \\
\text { ada objeknya }\end{array}$ \\
\hline 4 & vi & 1 & $\begin{array}{l}\text { Oleh karena itu } \\
\text { sangat terbuka } \\
\text { untuk terus-menerus } \\
\text { dilakukan perbaikan } \\
\text { dan penyempurnaan. }\end{array}$ & $\begin{array}{l}\text { Oleh karena itu, } \\
\text { sangat terbu- } \\
\text { ka kesempatan } \\
\text { untuk melakukan } \\
\text { perbaikan dan } \\
\text { penyempurnaan } \\
\text { terhadap buku ini. }\end{array}$ & $\begin{array}{l}\text { Kalimat belum } \\
\text { lengkap }\end{array}$ \\
\hline
\end{tabular}

a. Buku Guru Bahasa Arab Pendekatan Saintifik Kurikulum 2013, Madrasah Ibtidaiyah Kelas I 
Tabel 4. Daftar Temuan pada Aspek Kelayakan Isi Buku Guru Bahasa Arab Madrasah Ibtidayah Kelas I

\begin{tabular}{|c|c|c|c|c|c|}
\hline NO & HLM & POSISI TEKS & $\begin{array}{l}\text { TEMUAN } \\
\text { KESALAHAN }\end{array}$ & PEMBETULAN & KETERANGAN \\
\hline 1 & $\mathrm{i}$ & & $\begin{array}{lr}\text { Abdi } & \text { Pemi } \\
\text { Karyanto, } & \text { Abdul } \\
\text { aziz, } & \text { Mugy } \\
\text { Nugraha } & \\
\end{array}$ & $\begin{array}{lr}\text { Abdi } & \text { Pemi } \\
\text { Karyanto, } & \text { Abdul } \\
\text { Aziz, } & \text { Mugy } \\
\text { Nugraha } & \\
\end{array}$ & $\begin{array}{l}\text { Nama orang } \\
\text { diawali dengan } \\
\text { huruf kapital }\end{array}$ \\
\hline 2 & xiii & Table 2 baris 4 & آلسَبْبُورَةُ & آلسَّبُوْرَةُُ8 & Kurang tasydī d \\
\hline 3 & $\begin{array}{l}\text { xiii } \\
\text { xiv }\end{array}$ & $\begin{array}{l}\text { Table } 2 \text { baris } 5 \\
\text { Table } 2 \text { baris } 5\end{array}$ & & اََجِبْ & $\begin{array}{l}\text { Alif di awal tidak } \\
\text { panjang }\end{array}$ \\
\hline 4 & xiv & $\begin{array}{l}\text { Kolom } 1 \text { baris } \\
3,4,7,8 \\
\text { Kolom } 2 \text { baris } \\
3 \text { dan } 7\end{array}$ & 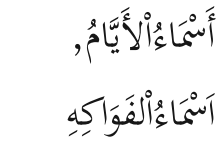 & لَالَأَيََّمَ, & $\begin{array}{l}\text { Kesalahan pada } \\
\text { penulisan hamzah } \\
\text { dan harakat di akgur } \\
\text { kata }\end{array}$ \\
\hline 5 & $\begin{array}{c}1,6 \\
11,17 \\
22,30 \\
34\end{array}$ & & دَرْنُسنَا الْآنَ & دَرُْْسنَا الْآَنَ & \\
\hline
\end{tabular}

Tabel 5. Daftar Temuan pada Aspek Kelayakan Penyajian Buku Guru Bahasa Arab Madrasah Ibtidaiyah Kelas I

\begin{tabular}{|c|c|c|c|c|c|c|}
\hline \multirow{2}{*}{ No } & \multirow{2}{*}{ HLM } & \multicolumn{2}{|c|}{ POSISI TEKS } & \multirow{2}{*}{$\begin{array}{l}\text { TEMUAN } \\
\text { KESALAHAN }\end{array}$} & \multirow{2}{*}{ PEMBETULAN } & \multirow{2}{*}{ KETERANGAN } \\
\hline & & Nomor & Alinea & & & \\
\hline 1 & $\begin{array}{l}x i, \quad x v i i, \\
24, \\
32\end{array}$ & \multicolumn{2}{|c|}{ Di akhir halaman } & $\begin{array}{l}\text { Ditemukan beber- } \\
\text { apa baris pertama } \\
\text { dalam alinea yang } \\
\text { terpisah dengan } \\
\text { bagian berikutnya } \\
\text { karena berapa di } \\
\text { akhir halaman }\end{array}$ & $\begin{array}{l}\text { Dipindahkan saja } \\
\text { ke halaman beri- } \\
\text { kutnya }\end{array}$ & $\begin{array}{l}\text { Menyebabab- } \\
\text { kan pemahaman } \\
\text { yang tidak utuh }\end{array}$ \\
\hline 2 & iii, iv, v & \multicolumn{2}{|c|}{ Di akhir baris } & $\begin{array}{l}\text { Pada pengantar, } \\
\text { ditemukan banyak } \\
\text { sekali kata yang } \\
\text { dipenggal suku } \\
\text { katanya karena dip- } \\
\text { isahkan oleh baris } \\
\text { berikutnya. }\end{array}$ & $\begin{array}{l}\text { Untuk mengh- } \\
\text { indari pemaha- } \\
\text { man yang tidak } \\
\text { utuh sebaiknya } \\
\text { disatukan saja. }\end{array}$ & \\
\hline
\end{tabular}


Tabel 6. Daftar Temuan pada Aspek Kelayakan Bahasa Buku Guru Bahasa Arab Madrasah Ibtidaiyah Kelas I

\begin{tabular}{|c|c|c|c|c|c|}
\hline No & HLM & $\begin{array}{l}\text { POSISI } \\
\text { TEKS }\end{array}$ & $\begin{array}{l}\text { TEMUAN } \\
\text { KESALAHAN }\end{array}$ & PEMBETULAN & $\begin{array}{l}\text { KETERAN- } \\
\text { GAN }\end{array}$ \\
\hline 1 & $x$ & Baris 1 & $\begin{array}{l}\text { Maksud Tujuan Mata } \\
\text { Pelajaran Bahasa } \\
\text { Arab }\end{array}$ & $\begin{array}{l}\text { Maksud dan Tujuan } \\
\text { Mata Pelajaran } \\
\text { Bahasa Arab }\end{array}$ & \\
\hline 2 & $x$ & $\begin{array}{l}\text { Alinea } 1 \\
\text { baris terahir }\end{array}$ & teruwjudnya & terwujudnya & Salah tulis \\
\hline 3 & $x$ & & $\begin{array}{l}\text { keseimbangan } \\
\text { kompetensi } \\
\text { sikap,pengeta- } \\
\text { huan,dan keterampi- } \\
\text { lan,maka }\end{array}$ & $\begin{array}{l}\text { kompetensi sikap, } \\
\text { pengetahuan, dan } \\
\text { keterampilan, maka }\end{array}$ & Kurang spasi \\
\hline 4 & $\begin{array}{l}\text { x dan seter- } \\
\text { usnya }\end{array}$ & & $\begin{array}{l}\text { dars, tadribat, mufra- } \\
\text { dat, slide, tadrib }\end{array}$ & $\begin{array}{l}\text { dars, tadribāt, mu- } \\
\text { fradāt, slide, tadrib }\end{array}$ & $\begin{array}{l}\text { Diceetak } \\
\text { miring, }\end{array}$ \\
\hline 5 & 14 & Alinea ke 2 & $\begin{array}{l}\text { dialog } \\
\text { perkenalan yang } \\
\text { benar.Pada latihan } \\
\text { ini,guru terlebih da- } \\
\text { hulu membacakan }\end{array}$ & $\begin{array}{l}\text { dialog } \\
\text { perkenalan yang } \\
\text { benar. Pada latihan } \\
\text { ini, guru terlebih } \\
\text { dahulu memba- } \\
\text { cakan }\end{array}$ & $\begin{array}{l}\text { Kurang spasi } \\
\text { setelah tanda } \\
\text { baca }\end{array}$ \\
\hline 6 & 14 & Alinea ke 3 & $\begin{array}{l}\text { memberikan nomor } \\
\text { pada kotak. } \backslash\end{array}$ & $\begin{array}{l}\text { memberikan nomor } \\
\text { pada kotak. }\end{array}$ & $\begin{array}{l}\text { Kelebihan } \\
\text { tanda baca }\end{array}$ \\
\hline 7 & $\begin{array}{l}\text { Di beberapa } \\
\text { halaman }\end{array}$ & & $\begin{array}{l}\text { Guru memastikan } \\
\text { apakah peserta didik } \\
\text { benar-benar mema- } \\
\text { hami } \\
\text { makna ungkapan-un- } \\
\text { gkapan? }\end{array}$ & $\begin{array}{l}\text { Guru memastikan } \\
\text { apakah peserta } \\
\text { didik benar-benar } \\
\text { memahami } \\
\text { makna ungka- } \\
\text { pan-ungkapan }\end{array}$ & $\begin{array}{l}\text { Tidak perlu } \\
\text { menggu- } \\
\text { nakan tanda } \\
\text { tanya }\end{array}$ \\
\hline
\end{tabular}

Tabel 7. Daftar Temuan pada Aspek Tadqiq Buku Guru Bahasa Arab Madrasah Ibtidaiyah Kelas I

\begin{tabular}{|r|l|l|l|l|l|}
\hline NO & HLM & POSISI TEKS & $\begin{array}{c}\text { TEMUAN } \\
\text { KESALAHAN }\end{array}$ & $\begin{array}{l}\text { PEMBETU- } \\
\text { LAN }\end{array}$ & KETERANGAN \\
\hline 1 & $\begin{array}{l}\text { Ada di tiap } \\
\text { bab }\end{array}$ & $\begin{array}{l}\text { Proses Pem- } \\
\text { belajaran, } \\
\text { Pendahuluan } \\
\text { No. 5 }\end{array}$ & $\begin{array}{l}\text { Darsuna al-Aan, } \\
\text { Al-Lughotu } \\
\text { Al-Arobiyah }\end{array}$ & $\begin{array}{l}\text { Darsunā al- } \\
\text { ân al-lugah } \\
\text { al-'arabiyyah }\end{array}$ & $\begin{array}{l}\text { SKB Menteri } \\
\text { Agama dan } \\
\text { Menteri P\&K RI } \\
\text { no. 158/1987 } \\
\text { dan No. 0543 } \\
\text { b/U/1987 }\end{array}$ \\
\hline 2 & & & $\begin{array}{l}\text { tadribat, mufra- } \\
\text { dat, tadrib }\end{array}$ & $\begin{array}{l}\text { tadrībāt, } \\
\text { mufradāt, } \\
\text { tadrīb }\end{array}$ & \\
\hline
\end{tabular}


1. Pembahasan

\section{Buku Siswa Bahasa Arab pendekatan Saintifik Kurikulum, 2013 Madrasah Ibtidaiyah Kelas I}

\section{a. Aspek Isi.}

Penilaian pada aspek isi meliputi beberapa subaspek yaitu: nilai dan norma kebangsaan, materi dan isi buku, relevansi, manfaat, kecukupan, keakuratan, kemutakhiran metoda, kemaknaan dan proporsionalitas. Dari hasil penilaian pada subaspek nilai dan norma kebangsaan, secara keseluruhan, isi buku siswa Bahasa Arab MI kelas I ini, mampu menjaga persatuan dan kesatuan bangsa serta terhindar dari unsur ketidakpatutan. Materi yang disajikan dalam buku ini tidak mengandung unsur pornografi, ekstrimisne dan radikalisme, kekerasan dan penistaan, SARA, bias gender, ujaran kebencian, serta penyimpangan dalam bentuk lainnya.

Pada subaspek materi dan isi buku, buku siswa belum memuat maksud, tujuan dan ruang lingkup; kompetensi inti dan kompetensi dasar; serta petunjuk penyajian buku. Buku ini sudah memuat instrumen penilaian pembelajaran, baik penilaian ranah kognitif maupun psikomotorik. Secara keseluruhan, materi pada buku ini sudah mendukung ketercapaian kompetensi sesuai kurikulum yang berlaku. Namun, dari sisi kesesuaian dengan perkembangan kognisi dan psikologi peserta didik, buku ini memiliki tingkat kesulitan yang terlalu tinggi untuk anak usia kelas I madrasah Ibtidaiyah.

Anak usia kelas I MI, belum semuanya mengenal huruf, apalagi huruf hijaiyah. Ketika dihadapkan dengan materi yang begitu rumit, ini akan sangat membebani peserta didik dalam belajar. Materi yang disajikanpun terlalu luas dan terlalu banyak. Meskipun pada dasarnya materi yang disajikan sesuai dengan kompetensi yang dibebankan pada kurikulumnya. Soal-soal yang disajikan pun sebenarnya sudah sesuai dengan kompetensi yang dimuat dalam kurikulum. Akan tetapi sangat jauh dengan kemampuan peserta didik yang masih kelas I MI. Oleh karena itu, perbaikan yang semestinya dilakukan adalah perbaikan pada kompetensi dasar yang akan diajarkan untuk anak usia kelas I MI.

Secara kecukupan materi, buku ini belum sesuai dengan tingkat pemahaman peserta didik. Buku ini memuat banyak gambar yang tidak sesuai dengan konteks kehidupan peserta didik. Meskipun begitu, struktur kalimat dan bahasa yang disampaikan terlalu rumit untuk anak yang baru belajar Bahasa Arab. Huruf yang digunakan agak menyulitkan peserta didik untuk membacanya secara mudah, baik, dan benar. 
Kompetensi yang tertuang dalam tuntunan kurikulumnya, semestinya bisa disederhanakan dan disesuaikan dengan tingkat perkembangan bahasa peserta didik. Pada subaspek keakuratan materi, terdapat banyak kesalahan penulisan dalam buku ini, terutama pada penulisan alif dan hamzah yang tidak sesuai dengan kaidah bahasa Arab. Kesalahan lain juga ditemukan yaitu pada penggunaan ism nakirah dan ism ma'rifah, sehingga perlu diadakan pembetulan secara cermat.

Metode yang disampaikan sangat monoton, kurang variatif, dan hanya copy paste saja dari bab I sampai bab VIII. Kaitannya dengan hal ini, pelajaran dalam buku ini bisa didesain dengan pembelajaran yang lebih menyenangkan melalui lagu-lagu, permainan bahasa, dan lain-lain yang mampu menumbuhkan kecintaan peserta didik terhadap bahasa Arab.

Beberapa latihan yang disajikan, belum menggunakan petunjuk yang jelas, sehingga menyulitkan siswa ketika ingin belajar secara mandiri. Secara keseluruhan, materi bahasa Arab yang dsajikan sudah memiliki makna yang utuh, baik dalam bab, subbab maupun alinea. Uraian yang disajikan juga sudah memiliki proporsionalitas antara bahasan dan pendukungnya. Namun, materi yang disampaikan kurang sesuai dengan perkembangan kognitif, afektif maupun psikomotorik peserta didik meskipun memiliki keseimbangan antara teori dan realita sehari-hari.

\section{b. Aspek Penyajian}

Pada aspek penyajian, buku ini kurang memenuhi kelengkapan sajian. Buku tidak memuat kompetensi yang harus dikuasai peserta didik, dan tidak menuliskan tujuan pembelajaran sesuai materi. Namun dari teknik penyajian, buku ini sudah sistematik, runtut, konsisten, dan seimbang antar babnya. Namun begitu, materi yang disajikan terkesan sangat padat, dengan ukuran tulisan yang terlalu kecil untuk anak usisa kelas I MI. Sementara itu, dari aspek pendudukung sajian, belum memuat daftar pendukung yang lengkap. Buku ini tidak memuat daftar indek, daftar gambar, daftar tabel, peta konsep, rangkuman glosarium dan pedoman transliterasi.

Dari aspek aktivitas pembelajaran, sudah perpusat pada peserta didik, melibatkan peserta didik, namun, kurang merangsang metakognisi, kedalaman berfikir dan berfikir kritis. Materi disampaiakn dengan cara yang sama dari bab pertama sampai bab terakhir. Peserta didik kurang diberikan ruang untuk mencari sendiri makna kosa kata yang disampaikan dengan cara 
yang lebih menarik, misalnya dengan teka-teki silang, lagu-lagu dan lain-lain.

\section{c. Aspek Bahasa}

BahasaArabyang dipergunakan dalam buku ini belum sesuai dengan perkembangan peserta didik yang notabene nya belum mengenal huruf hijaiyah, dan menyulitkan peserta didik dalam memahaminya. Bahasa Arab yang digunakan kurang sesuai dengan perkembangan bahasa, berfikir, emosi, sosial dan spiritual peserta didik. Ilustrasi yang disajikan sudah sesuai dengan substansi materi, namun belum mampu memotivasi dan menstimulasi peserta didik untuk membacanya, karena belum menyajikan gambar-gambar yang konkret yang ada dalam konteks kehidupan peserta didik sehari-hari. Buku ini tidak banyak menyajikan pembahasan dalam Bahasa Indonesisa, namun dari sedikit penyajian gagasan dalam Bahasa Indonesia tersebut, terdapat beberapa kalimat yang belum sempurna, beberapa kekurangan dalam penggunaan tanda baca, serta terdapat pemenggalan kata dan kalimat yang tidak pada tempatnya, sehingga mengurangi keutuhan makna, baik dalam kalimat maupun alinea.

\section{d. Aspek Kegrafikaan}

Berkaitan dengan desain grafis, secara keseluruhan cukup bagus. Namun, tampilannya terlalu padat, huruf yang digunakan belum bisa memudahkan siswa untuk anak usia MI kelas I dalam membaca. Meskipun begitu, buku ini memiliki keteraturan isi dari sisi tata letak, spasi antar paragraf, penempatan judul, serta proporsionalitas. Ilustarsi yang disajikan mampu memberikan gambaran yang memudahkan peserta didik untuk memahami materi yang disampaikan. Namun, ada sedikit warna background yang kurang kontras dengan warna tulisan, yaitu pada sub judul, sehingga mengurangi keterbacaan tulisan. Dalam pengantar juga terdapat banyak pemenggalan (pemisahan) suku kata karena perpindahan baris. Pada bagian ini terdapat kepala alinea yang dipisahkan dengan bagian berikutnya karena pergantian halaman sehingga mengurangi keutuhan makna kalimat, dan paragraf.

\section{Buku Guru Bahasa Arab Pendekatan Saintifik Kurikulum 2013, Madrasah Ibtidaiyah Kelas I}

\section{a. Aspek Isi}

Kompetensi dasar Bahasa Arab pada kelas 1 Madrasah Ibtidaiyah difokuskan pada keterampilan menyimak, membaca 
dan berbicara. Sementara keterampilan menulis belum begitu mendapatkan perhatian, sehingga buku guru dan buku siswa yang disusunpun belum menerapkan keterampilan menulis. Buku guru yang disusun untuk materi Bahasa Arab kelas 1 Madrasah Ibtidaiyah ini, secara umum hanya manyampilkan rencana pelaksanaan pembelajaran, dan langkah-langkah penilaian yang digunakan dalam kelas. Buku ini tidak memuat rincian materi, baik materi inti, materi untuk remedial maupun untuk pengayaan. Dari hasil penilaian didapatkan beberapa temuan, antara lain, kesalahan yang berulang dalam i'rab, kesalahan harakat dan penulisan hamzah dan alif.

Tahapan-tahapan dalam mengajarkan kosa kata baru dari pelajaran I sampai VIII menggunakan metode yang sama, yaitu dengan metode langsung. Guru belum memfasilitasi peserta didik untuk menemukan kosa kata dan artinya dengan cara yang lebih kreatif dan inovatif. Metode saintifik yang disajikan juga belum seimbang antara keterampilan yang satu dengan keterampilan yang lainnya. Siswa belum diberi kesempatan untuk bertanya lebih banyak tenatng materi.

Terkait penilaian, aspek kognitif, sudah cukup memadai namun perlu disampaikan dengan cara yang bervariatif dan kreatif salah satunya dengan permainan bahasa seperti kuis, teka-teki silang, lagulagu dan lain-lain. Format penilaian sikap dan pelaksanaannya tidak sesuai dengan pedoman penilaian dalam kurikulum 2013 yang terbaru. Antara ranah penilaian dan aspek yang dinilai tidak sinkron. Penilaian ranah pengetahuan bercampur dengan penilaian ranah keterampilan. Aspek penilaiannya tidak dijabarkan ke dalam indikatorindikator penilaian sehingga susah menentukan ukuran. Buku guru ini juga tidak memuat form penilaian aspek kinerja yang sangat dibutuhkan dalam keterampilan berbahasa

\section{b. Aspek Penyajian}

Pada aspek kelayakan penyajian, materi yang disajikan sudah runtut, sistematis dan dengan bahasa yang lugas. Namun dalam buku guru ini tidak memuat materi secara rinci, baik materi inti, materi untuk pengayaan maupun materi remedial. Tahapan-tahapan pembelajaran sudah disajikan secara berurutan sehingga saling terkait satu dengan yang lainnya. Aktifitas pembelajaran yang disajikan sudah menunjukkan tahapan pembelajaran. Namun semua pelajaran disajikan dengan aktifitas yang sama. Buku ini kurang menyajikan tahapan pembelajaran yang kreatif, inovatif, dan menyenangkan sesuai tuntutan kurikulum 2013. sehingga kurang mampu mengembangkan daya 
inovasi dan perfikir kreatif. Buku ini tidak dilengkapi dengan glosarium serta daftar indeks.

\section{c. Aspek Bahasa}

Secara umum bahasa yang digunakan sudah sesuai dengan peruntukan buku, namun masih banyak ditemukan beberapa kesalahan dalam penulisan seperti penulisan kosa kata asing yang tidak dicetak miring, kurang spasi, pemenggalan suku kata yang kurang pas, kelebihan tanda baca dan lain-lain.

\section{d. Aspek Kegrafikaan}

Pada aspek kegrafikaan, dari unsur tata letak, masih banyak ditemukan jarak antarparagraf yang tidak proporsional, dan tidak konsisten, sehingga kelihatan kosong di beberapa tempat. Di beberapa bagian halaman paling bawah, terdapat satu baris pertama pada alinea yang menggantung. Tipografi sudah memadai, tetapi masih ditemukan kesalahan seperti kekurangan spasi, kelebihan tanda baca, dan sebagainya, yang mengganggu aspek keterbacaan buku.

\section{e. Aspek Tadqiq.}

Pada dasarnya tidak banyak terdapat unsur tadqiq dalam buku guru ini, namun masih terdapat ketidaksesuaian transliterasi dengan pedoman yang telah ditetapkan. Untuk aspek tadqiq pada buku mata pelajaran Madrasah Ibtidaiyah, tidak diperhitungkan dalam penilaian buku, akan tetapi untuk kelengkapan hasil penilaian ini, penulis lampirkan hasil penilaian pada aspek tadqiq

\section{PENUTUP}

\section{Simpulan}

Setelah melalui penilaian pada bebagai aspek terhadap Buku Guru dan Buku Siswa Bahasa Arab MI Kelas 1, dapat disimpulan bahwa:

a. Buku Siswa Bahasa Arab kelas I Madrasah Ibtidaiyah ini, memuat materi yang terlalu rumit, belum sesuai dengan tingkat perkembangan bahasa, berfikir, emosi dan psikologi peserta didik. Anak kelas I MI, belum semua mengenal huruf, apalagi huruf hijaiyah. Pemilihan fontnya masih menyulitkan peserta didik dalam membaca tulisannya.

b. Terlebih lagi penyambungan kalimat yang agak rumit.

c. Muatan materi yang disajikan terlalu luas dan terlalu banyak untuk usia anak MI

d. Dari aspek kebahasaan, masih ada beberapa kesalahan konsep, terutama pada penggunaan alif dan hamzah 
e. serta penggunaan ism nakirah dan ism ma'rifah.

f. Masih ditemukan beberapa kesalahan dalam penulisan

g. Metode pembelajaran yang digunakan dalam buku siswa dan buku guru terlalu monoton, kurang variatif, sehingga kurang mampu merangsang proses berfikir yang kreatif dan inovatif serta proses berfikir kritis.

h. Pada aspek tadqiq, stransliterasi yang diterapkan belum sesuai dengan standar Kementerian Agama.

\section{Rekomendasi}

Dari simpulan di atas, maka rekomendasi untuk perbaikan buku ini adalah:

a. Perlu telaah lebih lanjut terhadap kompetensi dasar pada mata pelajaran Bahasa Arab MI kelas I, untuk disesuaikan dengan perkembangan bahasa, emosi, psikologi dan kognitif peserta didik

b. Perlu penyederhanaan materi, diawali dengan pengenalan huruf hijaiyah, harakatnya, makharijul huruf-nya, penulisannya, serta dilakukan dengan cara bertahap. Juduljudul materi juga perlu lebih disederhanakan contohnya dengan menggunakan

kalimat : لصفل| يف untuk bahasan تيساردلا تاؤدأل : dan sebagainya.

c. Perlu penyesuaian dengan KI dan KD yang ada pada KMA no. 165 Tahun 2014, serta pengembangan indikator pembelajaran yang mengacu kepada KI dan KD yang termuat dalam KMA tersebut.

d. Buku guru hendaknya dilengkapi lagi dengan pendalaman materi siswa (Materi pengayaan dan remedial), Langkah-langkah Pembelajarannya, selayaknya disajikan dengan cara yang lebih kreatif, menarik, inovatif, bukan sekedar copy paste dari langkah-langkah pembelajaran dari bab I sampai seterusnya. Perlu eksplorasi lebih banyak dalam penerapan langkahlangkah pembelajaran saintifik.

e. Format penilaian yang digunakan dalam buku guru, perlu disesuaikan dengan format penilaian kurikulum 2013 yang ada dalam panduan penilaian terbaru, (dipisahkan antara penilaian aspek kognotif, afektif dan psikomotorik). 


\section{DAFTAR PUSTAKA}

Badan Pengembangan Sumber Daya Manusia Pendidikan dan Kebudayaan dan Penjaminan Mutu Pendidikan, 2013, Materi Pelatihan Guru Implementasi Kurikulum 2013. Jakarta: Kementerian Pendidikan dan Kebudayaan.

Darwis, A. Sulaiman. 1989. Pengantar Kepada Teori dan Praktek Pengajaran. Semarang: IKIP Press, 1979

Departemen Agama RI, 2009, Laporan Penyelenggaraan Tadqiq Lektur Keagamaan. Badan Litbang dan Diklat Departemen Agama RI, Puslitbang Lektur Keagamaan.

Direktorat Urusan Agama Islam dan Pembinaan Syari'ah, 2012, Alquran dan Terjemahnya. Direktorat Jendral Bimbingan Masyarakat Islam

https://kbbi.web.id/Kamus Besar Bahasa Indonesia (KBBI), Kamus versi online/daring (dalam jaringan).

(http://www.nu.or.id/post/read/73142/masih-ada-ketidaktepatan pengutipan-quran-dalam-buku-teks-agama-islam)

Idham, 2016, Menyoal Buku Ajar Keagamaan: tadqiq Buku mata Kuliah Pendidikan Agama Islam di Universitas Negeri Gorontalo. Makassar, Balai Penelitian dan Pengembangan Agama.

Kementerian Agama Republik Indonesia, 2014, Buku Guru Bahasa Arab Pendekatan Saitifik Kurikulum 2013 Madrasah Ibtidaiyah Kelas I. Jakarta: Direktorat Jenderal Pendidikan Islam.

Kementerian Agama Republik Indonesia, 2014, Buku Siswa Bahasa Arab Pendekan Saintifik Kurikulum 2013. Madrasah Ibtidaiyah Kelas I. Jakarta: Direktorat Jendral Pendidikan Islam.

Lampiran Keputusan Menteri Agama Republik Indonesia Nomor: 165 Tahun 2014 Tentang Kurikulum 2013 Mata Pelajaran Pendidikan Agama Islam Dan Bahasa Arab Pada Madrasah

Peraturan Menteri Agama Republik Indonesia Nomor: 165 Tahun 2014 Tentang Kurikulum 2013 Mata Pelajaran Pendidikan Agama Islam dan Bahasa Arab Pada Madrasah. Jakarta: Kmenterian Agama RI

Shobirin, Ma'as, 2016, Konsep dan Implementasi Kurikulum 2013 di Sekolah Dasar. Yogyakart: Deepublish

SKB Menteri Agama dan Menteri P\&K RI no. 158/1987 dan No. 0543 b/U/1987 tertanggal 22 Januari 1988. 